This article has been accepted for publication by Edinburgh University Press in Edinburgh Law Review. The final published version can be found at:

http://www.euppublishing.com/loi/elr

\title{
BREXIT AND ENERGY IN SCOTLAND
}

\author{
Gavin Little*
}

\section{A. INTRODUCTION}

Brexit, however it emerges (and assuming that it will emerge), poses two key questions for energy governance and regulation in Scotland. Firstly, what impact might it have on Scotland's energy strategy? Secondly, what are its possible UK-wide effects?

\section{B. BREXIT AND SCOTLAND'S ENERGY STRATEGY}

Brexit is taking place at an important stage in the development of Scotland's energy sector. ${ }^{1}$ Over the past ten years, there have been major shifts, driven by UK and Scottish legislation and government policy, to reduce reliance on fossil fuels in order to mitigate climate change. Building on the UK Climate Change Act 2008, the Scottish Parliament's Climate Change (Scotland) Act 2009 set the ambitious statutory target of reducing Scotland's carbon emissions by $80 \%$ by $2050 .^{2}$ The Scottish Government will soon be introducing a new Climate Change (Scotland) Bill with even more challenging objectives, including increasing the 2050 target to a $90 \%$ emissions reduction. ${ }^{3}$

As a result of technological developments and government support, there have been significant changes to electricity generation in particular: renewable electricity (principally wind turbines and historic hydro-electricity) now accounts for nearly $60 \%$ of Scotland's electricity generation, with most of the rest being provided by the country's nuclear power stations, which generate low-carbon - although not renewable - electricity. ${ }^{4}$

Importantly, the 2017 Scottish Government Draft Energy Strategy, which will be finalised towards the end of the year, is also proposing the even more exacting objective that $50 \%$ of Scotland's energy consumption - its electricity and its transport and heating - is to be supplied from low-carbon, renewable sources by $2030 .{ }^{5}$ What makes achieving this goal so challenging is that electricity accounts for only around $20 \%$ of Scotland's total energy demand, with the remaining $80 \%$ in heating and transport. ${ }^{6}$ Moreover, while the changes to electricity generation have gone mainly unnoticed by consumers, reforming heating and transport is likely to be more difficult, as it will require individual consumers both to change their behaviour and spend money.

\footnotetext{
*Professor of Environmental and Public Law, Stirling Law School, University of Stirling.

${ }^{1}$ Scottish Government, Draft Scottish Energy Strategy: The Future of Energy in Scotland (24 January 2017) 9-13, available at: http://www.gov.scot/Publications/2017/01/3414.

${ }^{2}$ Climate Change (Scotland) Act 2009 s 1; and ibid 10.

${ }^{3}$ See further Scottish Government, Climate Change Bill - Consultation Paper (30 June 2017), available at: http://www.gov.scot/Publications/2017/06/8208.

${ }^{4}$ Scottish Government, Draft Scottish Energy Strategy, 17. NB The statistics presented in the draft strategy date from 2015: since then, Scotland's last coal-fired power station has closed, and the proportion generated by renewables has increased.

${ }^{5}$ Ibid, 10 .

${ }^{6}$ Ibid, 19.
} 
The final form of the Scottish Government's energy strategy remains to be seen, but it is doubtful that it will differ significantly from the draft version which has been out to consultation. As such, it is likely to be an ambitious strategy which articulates medium to longterm targets without focusing on the technical challenges that need to be overcome in order to achieve its goals. This is justifiable in a broad strategy, although just how achievable the targets are will no doubt be a matter for debate.

From an energy governance perspective, the strategy is significant in that it adds a further piece to the jigsaw of the Scottish Government's inter-related strategies. In particular, given the big picture nature of overall Scottish Government policy, the draft energy strategy and Scotland's Energy Efficiency Programme ("SEEP") ${ }^{7}$ currently fit together. As further progress is made with low-carbon transition in heating and transport, however, one of the things for energy law and policy specialists to monitor is whether aspects of the different strategies (together with their governance structures and legislative instruments) continue to be compatible with each other, or whether they start to diverge.

Given the lack of clarity on what Brexit might entail (although we now know that the UK may comply with EU law until 2021), it is difficult to be definitive about its possible impact on Scotland's energy strategy. That said, is reasonable to think that, even in the event of a socalled hard Brexit, it is unlikely that the broad thrust of the things that the strategy might want to do in relation to heating, transport and energy efficiency would be affected significantly in any substantive, legal sense - in the short term at least. As outlined below, however, Brexit may result in there being more political instability and less money to finance the low-carbon transition throughout the UK. There may also be less government and parliamentary time and resources available for energy policy-making, legislation and regulation.

In this context, it may be that political and constitutional fault-lines could become more acute, making it more difficult to maintain the broad consensus on energy within and between the Scottish and UK Governments that is needed to effect significant change. While in formal terms many of the legislative powers which govern the main aspects of the proposed Scottish Government strategy are reserved to Westminster, it is also the case that the Scottish Government has considerable devolved competence to act in key areas such as planning. Despite political differences in the aftermath of the 2014 independence referendum in particular, ${ }^{8}$ the two governments have often been able to co-operate on energy - but will Brexit affect this generally positive working relationship? At this stage, it is impossible to know.

That said, in this context an important issue for Scotland's future energy strategy is likely to be the effectiveness of the design of post-Brexit domestic regulatory regimes for heating, transport and energy efficiency. With the EU having left the field, the division between reserved and devolved areas may become even more critical, and the work of Thomas Muinzer and Geraint Ellis mapping the competencies of the devolved administrations in what they call the "energy constitution" exemplifies what can be done to develop understanding of how to facilitate policy delivery. ${ }^{9}$ Analysis of this sort could also be expanded to include a wider range

\footnotetext{
${ }^{7}$ For information on SEEP, see Scottish Government at: http://www.gov.scot/Topics/BusinessIndustry/Energy/Action/lowcarbon/LCITP/SEEP.

${ }^{8}$ See generally G Little, "Energy and the Scotland Act 2016" (2016) 20(3) Edinburgh Law Review 394-399.

${ }^{9} \mathrm{~T}$ L Muinzer and G Ellis, "Subnational governance for the low carbon energy transition: Mapping the UK's 'Energy Constitution"” (2017) Environment and Planning C: Politics and Space 1-22.
} 
of energy sector participants and to drill down into specific areas, such as heating and transport. A further issue to be grappled with is that the regulatory regime which is likely to be needed in the context of reforming provision for heating and transport will need to be different from the technocratic regime for electricity generation. This is because consumers - and changing their behaviour - will become a central factor, whatever emerges from Brexit.

\section{(1) The UK-wide effects of Brexit on energy}

As matters stand, all that can be said about Brexit with certainty is that, depending on its terms (which are still to be negotiated), it could have a major effect on important aspects of the UK's approach to energy. This section will therefore highlight the areas where Brexit may have particular impact: governance and finance; security of supply; and climate change and lowcarbon transition. The key points to note are as follows.

\section{(a) Governance and finance}

It is possible that after Brexit the UK may cease to be in the single European energy market, although current UK Government policy is to continue as part of it. Depending on what happens, there may be adverse cost implications for the UK energy sector (and therefore possibly consumers) and increased risks to UK energy security.

Outside the EU, the UK could continue to participate in some of the European organisations and agreements developing international energy transmission systems. ${ }^{10}$ It would, however, lose its representation on the EU Agency for the Cooperation of Energy Regulators ("ACER") ${ }^{11}$ and will leave the European Atomic Energy Community ("Euratom"). ${ }^{12}$

It remains to be seen whether the UK could have observer status at ACER, and negotiate some form of continued involvement with Euratom. Also in respect of ACER, the provisions of the EU Regulation on Wholesale Energy Market Integrity and Transparency ${ }^{13}$ ("REMIT") will still apply to UK-based energy suppliers delivering gas or electricity to EU Member States post-Brexit: they will therefore be required to meet ACER's reporting requirements and Member State level provision giving effect to REMIT.

As a non-EU state, the UK will also lose its ability to participate in decision-taking under the EU Regulation on Guidelines for Trans-European Energy Infrastructure ${ }^{14}$ (the "TENE Regulation"). This would, on the face of it, leave the UK out of the main EU system for the development of major energy projects of common interest ("PCIs") such as interconnectors. Importantly, the UK could also lose EU financial support - possibly for existing UK-focussed PCIs as well as post-Brexit ones. A particular issue is likely to arise in respect of interconnection with Ireland, which currently imports its electricity and gas via the UK (although perhaps not for much longer). ${ }^{15}$ Once more, it remains to be seen what the EU and

\footnotetext{
${ }^{10}$ IE the European Network of Transmission System Operators for Gas, the European Network of Transmission System Operators for Electricity and the European Network Treaty.

${ }^{11}$ For information on ACER, see http://www.acer.europa.eu/en/Pages/default.aspx.

${ }^{12}$ European Union (Notification of Withdrawal) Act $2017 \mathrm{~s} 1$. Euratom is part of the EU in this context and the UK is therefore leaving it as well as the EU.

${ }^{13}$ Commission Regulation 1227/2011 OJ 2011 L326.

${ }^{14}$ Commission Regulation 347/2013 OJ 2013 L115.

15 The European Commission has now approved the 'Celtic interconnector' as a PCI to offset the effect of Brexit on Ireland: if it proceeds, it will deliver 700MW of electricity from France to Ireland. Provisional EU
} 
UK may be able to agree in due course, on the assumption that, irrespective of Brexit, it is in everybody's interests to continue to have a highly integrated European energy infrastructure.

More specifically on the issue of finance, Brexit may have a significant impact on the UK. In particular, the European Investment Bank ("EIB"), ${ }^{16}$ which has as its main focus lending to EU Member States, provides large amounts of finance for UK energy projects. Whether, how or to what extent this will continue after the UK leaves the EU is unclear, although it would seem obvious that as a non-Member State the UK cannot expect to receive the level of support that it currently enjoys. Similarly, the post-Brexit UK may, on the face of it, no longer be eligible for European Fund for Strategic Investment ("EFSI") ${ }^{17}$ backing (or at least the same level of support), and this is an important factor in attracting private sector finance for major energy projects. Taken together with what may be a weakening UK economy caused by an overall lack of certainty created by Brexit, a changed relationship with the EIB and EFSI has the clear potential to have an adverse effect on the financing of the UK energy sector. Finally in this context, it could be argued that a post-Brexit UK might have greater scope for providing state aid for domestic energy projects. This would, however, depend on the outcome of future negotiations between the UK and EU: as matters stand, it is unclear whether and to what extent any trade deals which may come into effect after 2021 will require the UK to comply with EU state aid and competition law in the energy area. ${ }^{18}$

\section{(b) Security of supply}

The security of electricity supply is an increasingly important issue. Recently, the UK has come close to power cuts and the closure of fossil fuel power stations, together with an increased reliance on renewables, means that it needs to import electricity from Europe in a cost-effective way. It is difficult to say whether or not Brexit will have a significant impact in this context, as much depends on the terms of the UK's departure from the EU and future electricity pricing. That said, as noted above, the UK's departure from the TEN-E Regulation is likely to mean that it may become more difficult to develop PCIs (e.g. interconnectors to import electricity) that benefit the UK.

In terms of the security of gas supply, it is unlikely that even a hard Brexit would result in an immediate risk to the UK, which has access to its own (still) extensive gas fields in the North Sea, and is able to import from the US and elsewhere. There is, however, a reliance on EU interconnectors in extremis. So, again, if it becomes more difficult to develop PCIs postBrexit, this may affect the financing of new interconnectors, thereby - potentially - disrupting UK gas supply security.

(c) Climate change and low-carbon transition

Thus far, there has been little real indication that Brexit has had a significant impact on the approach taken by the UK to climate change and low-carbon transition. For example, the UK

\footnotetext{
support has also been given for the construction of a LNG terminal in Ireland. See D. Williams, 'Ireland pushes EU to assist in post-Brexit energy security’ Power Engineering International (26/7/2017), available at http://www.powerengineeringint.com/articles/2017/07/ireland-pushes-eu-to-assist-in-post-brexit-energysecurity.html.

${ }^{16}$ For information on the EIB, see http://www.eib.org/about/index.htm.

${ }^{17}$ For information on the EFSI, see http://www.eib.org/efsi/.

${ }^{18}$ N.B. If the UK is no longer subject to EU state aid rules, it will still be required to comply with (different)

World Trade Organisation rules.
} 
Government has inter alia ratified the Paris Agreement, followed the advice of the independent Committee on Climate Change on emissions reduction, continued to provide significant amounts of support for renewable energy, made announcements on phasing out petrol/diesel vehicles and made clear on the international stage that it remains wholly committed to lowcarbon transition, notwithstanding developments in US policy which are hostile to climate change mitigation.

Any immediate consequence of Brexit is therefore likely to be institutional and technical, rather than radical in policy terms. One obvious issue, however, is that the UK's target for emissions reduction under the UN Framework Convention on Climate Change and the Paris Agreement is subsumed within the overall EU target. ${ }^{19}$ So, something which will have to be determined is whether the post-Brexit UK will have a separate emissions reduction target, or whether it will continue as part of the EU target in some way.

In a similar (relatively) non-contentious vein, the UK's post-Brexit status in relation to the Emissions Trading Scheme will also require clarification. Much will no doubt depend on the outcome of future UK-EU negotiations, although one possibility could be to conjoin the EU and UK schemes, as the EU and Switzerland have just done. ${ }^{20}$

\section{CONCLUSION}

The implications of Brexit for energy governance and regulation remain uncertain: much will depend on the future relationship that the post-Brexit UK is able to establish with the EU. At this stage, however, it seems likely that the main consequences of Brexit for Scotland's energy strategy and the UK energy sector as a whole will be a more uncertain political environment, exclusion from the mainstream of strategic EU energy governance, and fewer financial resources for investment and development.

\footnotetext{
${ }^{19}$ Notwithstanding that the UK is a signatory to the conventions.

${ }^{20}$ See European Commission, EU and Switzerland join forces on emissions trading, available at:

https://ec.europa.eu/clima/news/eu-and-switzerland-join-forces-emissions-trading_en.
} 